\title{
IDENTIFIKASI KETIDAKSESUAIAN PERUNTUKAN RUANG KAWASAN LINDUNG SEMPADAN SUNGAI PEDINDANG DI KOTA PANGKALPINANG
}

\section{Agung Ferianda ${ }^{1}$ dan Bakti Setiawan ${ }^{2}$}

Dinas Kebudayaan dan Pariwisata Kabupaten Bangka, Bangka Belitung, Indonesial, Fakultas Geografi, Universitas Gadjah Mada, Indonesia ${ }^{2}$

andriboen@gmail.com

Diterima : November 2015 ; Direvisi : Juni 2016.; Dipubikasikan: September 2016

\begin{abstract}
ABSTRAK Penelitian ini tentang ketidaksesuaian area sungai pada kawasan lindung di Sungai Pedindang, Kota Pangkalpinang. Tujuan dari penelitian adalah (1) untuk mengindentifikasi ketidaksesuaian penggunaan kawasan lindung sempadan sungai; (2) untuk mengidentifikasi faktor-faktor yang mempengaruhi ketidaksesuaian penggunaan kawasan lindung sempadan sungai; (3) untuk mengetahui distribusi ketidaksesuaian penggunaan kawasan lindung sempadan sungai di Sungai Pedindang, Kota Pangkalpinang. Penelitian ini dilakukan dengan metode studi kasus. Lokasi yang dipilih berkaitan dengan ketidaksesuaian penggunaan sempadan sungai yang ditemukan di Sungai Pedindang, Kota Pangkalpinang. Penelitian ini difokuskan pada ketidaksesuaian kawasan lindung sepanjang sungai. Survei dilakukan dengan menyebarkan kuesioner. Data yang dikumpulkan dianalisis dengan teknik kualitatif. Hasil penelitian menunjukkan bahwa (1) terdapat ketidaksesuaian penggunaan kawasan lindung di sempadan Sungai Pedindang, Kota Pangkalpinang. Penggunaan kawasan lindung yang tidak sesuai didasarkan pada Peraturan Daerah Nomor 1 Tahun 2012 tentang RTRW dari Kota Pangkalpinang, untuk ruang terbuka hijau atau inspeksi jalan pada area terbangun. (2) Faktor-faktor yang mempengaruhi ketidaksesuaian penggunaan kawasan lindung di sungai Pedindang diantaranya (a) ketersediaan fasilitas di sekitar sempadan sungai, (b) tingkat keamanan lokasi, (c) tingginya tingkat pendapatan daerah perkotaan, (d) jumlah kesempatan kerja besar, dan (e) kedekatan dengan tempat bekerja. (3) Distribusi ketidaksesuaian di kawasan lindung sempadan sungai ditemukan di daerah tengah arus sungai yaitu daerah pusat Kota Pangkalpinang dengan populasi yang sangat padat.
\end{abstract}

Kata kunci: ketidaksesuaian tata ruang; sempadan sungai; sungai.

ABSTRACT This study is about the inappropriate use of protected riparian areas in Pedindang River in Pangkalpinang Municipality. The objectives of the study are (1) to identify the inappropriate use of protected riparian areas, (2) to identify the factors influencing the inappropriate use of protected riparian areas, and (3) to find out distribution of the inappropriate use of protected riparian areas, in this case in Pedindang River of Pangkalpinang Municipality. The study was conducted by a case study method. The location was selected because the problems related to the inappropriate use of protected riparian areas were found in Pangkalpinang Municipality, mostly in Pedindang River. The study was focused on the inappropriate use of protected riparian areas along the river. A sruvey was carried out by distributing questionnaires. The data collected were analyzed by a qualitative technique. The results of the study showed that (1) there was the inappropriate use of protected riparian areas in Pedindang River of Pangkalpinang Municipality. Such inappropriate use was indicated by the use of protected riparian areas, which are, based on Local Regulation Number 1 Year 2012 on RTRW of Pangkalpinang Municipality, for green open space or inspection streets in the built areas. (2) The factors influencing the inappropriate use of protected riparian areas in Pedindang River included (a) the availability of facilities around the protected riparian areas, (b) the high safety of the location, (c) the high rate of income in urban areas, (d) the large number of work opportunities, (e) the adjacency to work place. (3) The distribution of the inappropriate use of protected riparian areas was mostly found at the middle areas of river flows, but actually the case is that these are the central areas of Pangkalpinang Municipality with highly dense population.

Key words: inappropriate spatial use, riparian areas, river.

\section{PENDAHULUAN}

Para ahli di daerah perkotaan sepakat, penduduk perkotaan cenderung meningkat berkali lipat jumlahnya. Ini berarti peran perkotaan dalam kehidupan manusia, terutama dalam menentukan kualitas hidup homo urbanis menjadi sangat penting. Peningkatan kondisi lingkungan hidup di daerah perkotaan memiliki efek positif pada kualitas penduduk maupun sebaliknya (Yunus, 2008).

Mengacu pada karakteristik daerah sebagian besar bervariasi satu sama lain. Dalam Peraturan Pemerintah
Nomor 38 Tahun 2011 tentang Sungai, dijelaskan bahwa kebijakan perlindungan alih fungsi lahan pada kawasan lindung disesuaikan dengan masing-masing kondisi lingkungan dan daerah. Hal ini sesuai dengan Yunus (2008) yang menyatakan bahwa setiap daerah memiliki kondisi lingkungan yang berbeda satu sama lain dan kondisi lingkungan menciptakan karakteristik yang berbeda.

Di Kota Pangkalpinang, upaya pengendalian penggunaan wilayah sempadan sungai diatur dalam Peraturan Daerah Nomor 1 Tahun 2012 tentang Rencana Tata Ruang Wilayah Teritorial di Kota 
Pangkalpinang periode 2011-2030, yang menyebutkan kawasan lindung di sempadan sungai sangat dilarang untuk membangun segala bentuk bangunan permanen untuk tempat tinggal dan tempat usaha. Namun, dalam kondisi di lapangan, ditemukan adanya ketidaksesuaian pemanfaatan ruang. Oleh karena itu, sangat menarik untuk mengidentifikasi dan faktorfaktor yang mempengaruhi ketidaksesuaian dalam pemanfaatan ruang di kawasan lindung sempadan sungai Pedindang, Kota Pangkalpinang.

Masalah penggunaan spasial terkait dengan isu perkotaan. Menurut Yunus (2005), masalah yang dihadapi pemerintah kota relatif sama, yaitu terbatasnya ketersediaan ruang terbuka di perkotaan yang dibangun dalam daerah, dan bahkan di pusat perkotaan, dengan memanfaatkan ruang terbuka yang masih tersedia atau merehabilitasi fungsi bangunan yang ada dengan membuat intensifikasi fungsi dan membangun bangunan vertikal. Sementara itu, bagian dari ruang yang tidak dapat dibangun di daerah perkotaan dikarenakan kelangkaan ruang dan harga tanah yang sangat terjangkau sehingga mengalihkan perhatian ke daerah perkotaan marginal terhadap lahan terbuka yang tersedia.

Penelitian ini dilakukan di Kota Pangkalpinang terutama di sepanjang Sungai Pedindang dengan arus membelah Kota Pangkalpinang. Masalah utama adalah adanya ketidaksesuaian pemanfaatan ruang di daerah sempadan sungai. Dalam penelitian ini, ruang didefinisikan sebagai penggunaan kawasan lindung di sepanjang Sungai Pedindang, Kota Pangkalpinang dengan kondisi yang penuh bangunan di kawasan lindung sepanjang sempadan sungai.

Sesuai dengan Undang-Undang Tahun 1992 tentang Perumahan dan Permukinan, fasilitas lingkungan adalah fasilitas penunjang yang berfungsi untuk mengembangkan dan mendukung kehidupan social, ekonomi, dan budaya. Fasilitas lingkungan permukiman dalam penelitian ini mencakup layanan air bersih, jasa transportasi, perumahan, tempat untuk layanan dan bisnis perdagangan, dan pemerintahan daerah.

Bagian dari sungai sepanjang hulu sampai hilir adalah mata air pertama, hulu, tengah, hilir, dan muara. Aliran adalah habitat bagi ekosistem sungai (abiotik, biotik, flora, dan habitat fauna) dengan lahan terbuka dari hulu ke hilir. Bagian penampang sungai adalah genangan sungai dan sempadan sungai (Maryono, 2014). Dalam penelitian ini, sungai merupakan daerah dari Sungai Pedindang yang mengalir di Kota Pangkalpinang dimana hulu dan tengah sungai adalah pusat kota dan hilir sungai merupakan wilayah pinggiran kota.

Dalam penelitian tersebut, daerah sempadan sungai mengacu pada definisi daerah sempadan dalam Peraturan Menteri Pekerjaan Umum Nomor 63/PRT 1993, daerah sempadan adalah daerah sepanjang sisi kiri dan kanan sungai termasuk sungai buatan yang bermanfaat penting untuk menjaga kelestarian fungsi sungai. Berdasarkan Peraturan Pemerintah Nomor 38 Tahun 2001 (Bab 1 Pasal 1) fungsi daerah sempadan adalah untuk melindungi sungai dan sebagai daerah mendukung antara sungai dan ekosistem darat agar fungsi sungai dan ekosistem darat serta aktivitas manusia tidak saling terganggu.

Batas area sempadan dalam penelitian ini ditentukan oleh Pemerintah Pangkalpinang Kota sesuai dengan ketentuan dalam Peraturan Daerah Nomor 1 Tahun 2012 tentang Rencana Tata Ruang Wilayah Pangkalpinang dalam periode 2011-2030. Faktor yang mempengaruhi penggunaan kawasan lindung sempadan Sungai Pedindang, Kota Pangkalpinang yang tidak sesuai adalah (1) ketersediaan fasilitas di sekitar wilayah sempadan sungai; (2) keselamatan tinggi dari lokasi; (3) tingginya tingkat pendapatan di daerah perkotaan; (4) jumlah kesempatan kerja; dan (5) kedekatan jarak ke tempat kerja.

\section{METODE PENELITIAN}

Metode penelitian ditunjukkan pada Gambar 1. Penelitian di Sungai Pedindang, Kota Pangkalpinang dilakukan dengan mengamati bangunan dalam jarak kurang dari 3 meter dari tepi sungai yang seharusnya digunakan sebagai daerah ruang terbuka hijau. Daerah yang berdekatan dengan Sungai Pedindang terdiri dari 4 kecamatan dengan 8 kelurahan seperti yang tersaji dalam Tabel 1.

Tabel 1. Data Kecamatan dan Kelurahan yang Berdekatan dengan Sungai Pedindang

\begin{tabular}{ll}
\hline Kecamatan & Kelurahan \\
\hline Tamansari & Gedung Nasional \\
Bukit Intan & Pasir Putih \\
Rangkui & Parit Lalang \\
& Bintang \\
Girimaya & Semabung Baru \\
& Batu Intan \\
& Pasar Padi \\
& Sriwijaya \\
\hline
\end{tabular}

Untuk mempermudah pengamatan, peneliti membuat peta ketidaksesuaian penggunaan kawasan lindung sempadan Sungai Pedindang dengan 9 daerah. 
Hal ini dilakukan untuk mengamati secara detail bangunan pada jarak kurang dari 3 meter dari tepi sungai dan kemudian mencocokkannya dengan kondisi di lapangan. Data primer dikumpulak dengan wawancara ke responden terhadap persepsi masyarakat tentang pilihan penggunaan lahan di sekitar sungai. Kegiatan ini dilakukan untuk menemukan standar dan tersedianya data dalam instansi Pemerintah Kota Pangkalpinang. Pengumpulan data sekunder dilakukan dari laporan instansi dan buku literature, peraturan yang relevan, peta, rencana tata ruang wilayah, data kependudukan, dan data ekonomi.
Data yang dikumpulkan kemudian dianalisis dengan teknik deskriptif dalam bentuk tabel atau grafik dan peta. Variabel yang diteliti dalam kuesioner adalah sebagai berikut :

(1) Ketersediaan fasilitas di sekitar area sempadan sungai

(2) Keamanan lokasi

(3) Tingginya pendapatan di daerah perkotaan

(4) Banyaknya peluang kerja dan

(5) Kedekatan terhadap tempat kerja.

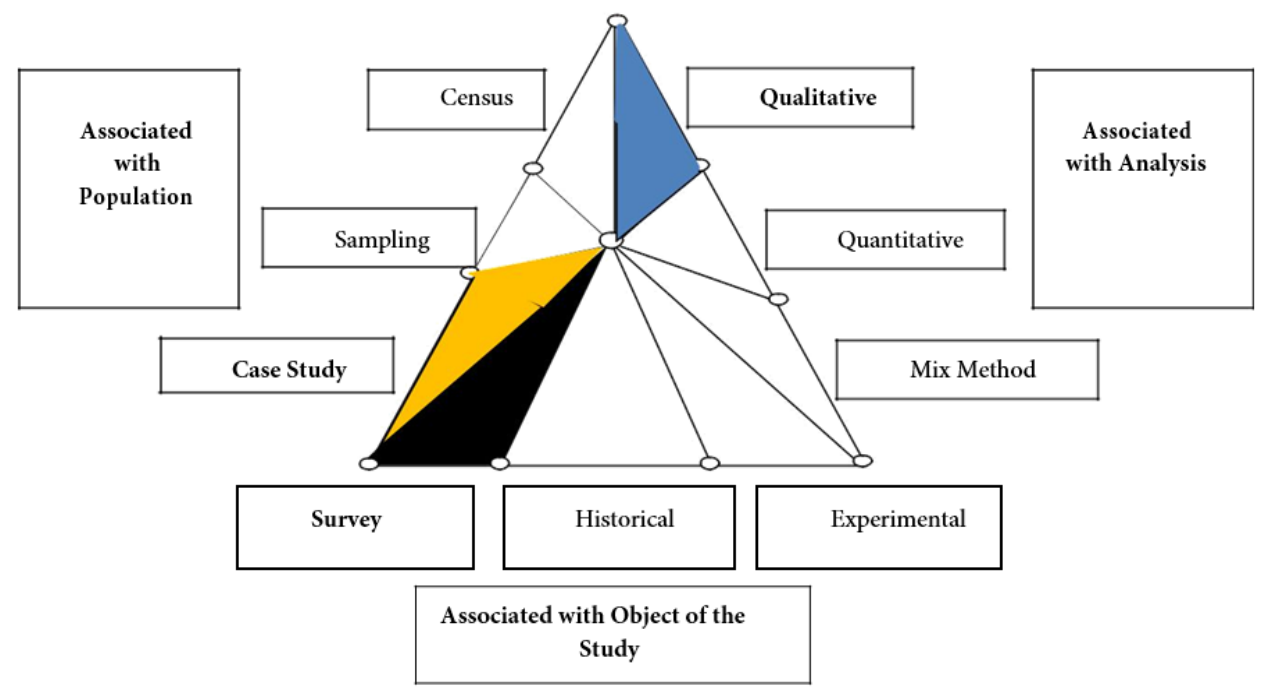

Gambar 1. Segitiga Metode Penelitian

HASIL DAN PEMBAHASAN

Kawasan Lindung Sempadan Sungai Pedindang Sesuai dengan Peraturan Daerah Nomor 1 Tahun 2012 Tentan RTRW Kota Pangkalpinang

Garis daerah sempadan Sungai Pedindang dididirikan sekitar 3 meter untuk kiri dan kana bagian sungai, sementara upaya konservasi daerah sempadan yang dilindungi sesuai dengan Pasal 38 (2) sebagai berikut : (a) menanam pohon untuk pencegahan erosi dan menghancurkan tepi sungai; (b) pengembangan inspeksi jalan di lahan terbangun; dan (c) pembangunan daerah sempadan di kedua sisi untuk mencegah banjir di sekitarnya.

\section{Ketidaksesuaian Penggunana Kawasan Lindung Sempadan Sungai Pedindang}

Berdasarkan survei yang dilakukan di wilayah Sungai Pedindang, peneliti mengidentifikasi beberapa tanah yang dibangun menggunakan daerah sepanjang sempadan sungai. Survei lapangan mengacu pada peta ketidaksesuaian penggunaan kawasan lindung di Kota Pangkalpinang berdasarkan overlay citra satelit dengan peta administrasi dan Peraturan Daerah Nomor 1 Tahun 2012 tentang Rencana Tata Ruang Wilayah Pangkalpinang periode 2011-2030.

\section{Pemetaan Kesesuaian Kawasan Lindung Sungai Pedindang, Pangkalpinang}

Pemetaan kesesuaian penggunaan tata ruang di sepanjang area sungai di Sungai Pedindang dilakukan dengan membuat overlay dari buffer sebesar 3 meter di sisi kanan dan kiri sungai (Gambar 2). Dari peta ketidaksesuaian penggunaan kawasan lindung di sempadan Sungai Pedindang, Pangkalpinang, dapat ditemukan bahwa terdapat 59 bangunan dengan jarak sesuai 3 meter di kiri dan kanan sungai. Wilayah tersebut adalah Kelurahan Bintang, Kecamatan Rangkui yang memiliki daerah paling terbangun, yaitu sebanyak 26 bangunan yang tidak sesuai (Tabel 2). Kondisi ini dipengaruhi oleh fakta bahwa sungai Pedindang mengalir melalui kawasan urban yang terletak di pusat Kota Pangkalpinang dengan padat penduduk. 


\section{Faktor yang Mempengaruhi Kesesuaian Penggunaan Kawasan Tata Ruang}

Berdasarkan yang ditemukan di lapangan, populasi yang tinggal di atas daerah sempadan sungai adalah karena spasial terkait dengan (1) ketersediaan fasilitasi di sekitar sungai, (2) keamanan lokasi, (3) tingginya tingkat pendapatan di daerah perkotaan, (4) besarnya peluang kerja, dan (5) kedekatan dengan tempat kerja. Hal ini sejalan dengan Colby di Yunus (2011), menyatakan faktor menarik dari orang-orang di daerah perkotaan. Aliran masuk dari penduduk pendatang baru di sempadan Sungai Pedindang mengakibatkan masalah pemanfaatan ruang yang tidak sesuai, sebagai tambahan dalam pengetahuan yang lebih rendah dari aturan spasial daerah. Dari 5 variabel di atas, faktorfaktor yang mempengaruhi ketidaksesuaian kawasan lindung di Sungai Pedindang dapat diklasifikasikan dalam Tabel 3.

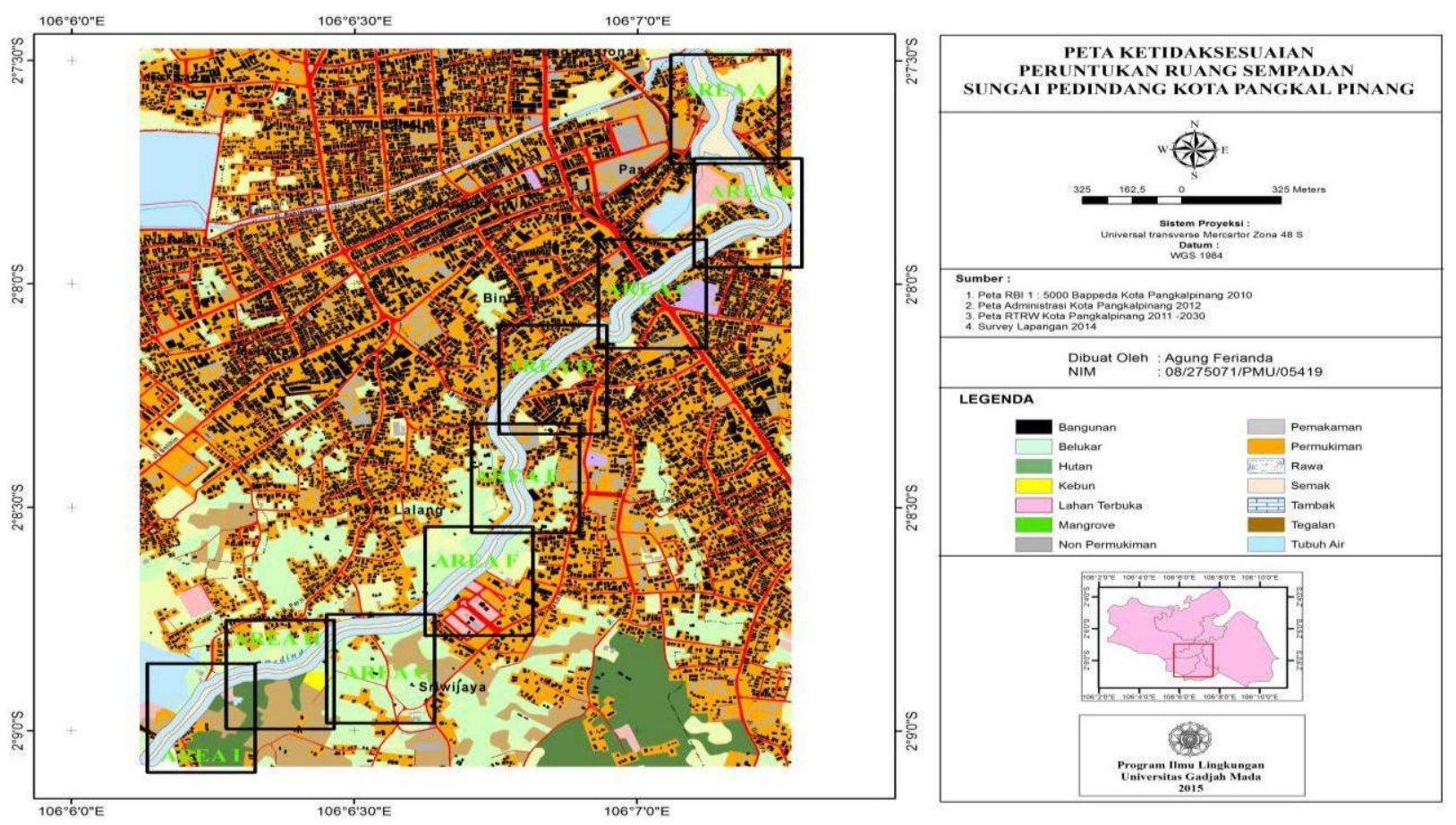

Gambar 1. Peta Kesesuaian Penggunaan Ruang Sempadan Sungai

Tabel 2. Bangunan di Sekitar Area Sempadan Sungai Pedindang Berdasarkan Daerah Penelitian

\begin{tabular}{cllclcc}
\hline & \multicolumn{3}{c}{ Right Limit of River (East) } & \multicolumn{3}{c}{ Left Limit of River (West) } \\
Area & Urban Village & Subdistrict & $\begin{array}{c}\text { Number of Buildings } \\
(0-3) \text { meter }\end{array}$ & Urban Village & Subdistrict & $\begin{array}{c}\text { Number of Buildings } \\
(0-3) \text { meter }\end{array}$ \\
\hline A & Pasir Putih & Bukit intan & 4 & Pasar Padi & Girimaya & 0 \\
B & Semabung Baru & Girimaya & 6 & Pasar Padi & Girimaya & 13 \\
C & Batu Intan & Girimaya & 0 & Bintang & Rangkui & 9 \\
D & Batu Intan & Girimaya & 5 & Bintang & Rangkui & 16 \\
E & Batu Intan & Girimaya & 3 & Bintang & Rangkui & 1 \\
F & Batu Intan & Girimaya & 0 & Parit Lalang & Rangkui & 0 \\
G & Sriwijaya & Girimaya & 0 & Parit Lalang & Rangkui & 0 \\
H & Sriwijaya & Girimaya & 2 & Parit Lalang & Rangkui & 0 \\
I & Sriwijaya & Girimaya & 0 & Parit Lalang & Rangkui & 0 \\
& \multicolumn{2}{c}{ Total Bangunan } & 20 & Total Bangunan & 39 \\
\hline
\end{tabular}


Tabel 3. Ringkasan Hasil Penelitian

\begin{tabular}{|c|c|c|c|}
\hline \multirow{2}{*}{ Faktor } & \multirow{2}{*}{ Indikator } & \multicolumn{2}{|c|}{ Jawaban } \\
\hline & & Setuju & Tidak Setuju \\
\hline \multirow{3}{*}{$\begin{array}{l}\text { Fasilitas di Sekitar Sempadan } \\
\text { Sungai }\end{array}$} & Fasilitas di sekitar lokasi penelitian & 59 & 0 \\
\hline & $\begin{array}{l}\text { Kepadatan lahan yang digunakan di daerah marjinal } \\
\text { sekitar lokasi penelitian }\end{array}$ & 56 & 2 \\
\hline & Ketersediaan telepon, listrik, air, dan fasilitas lainnya & 44 & 15 \\
\hline Total & & $74.50 \%$ & $22 \%$ \\
\hline \multirow[t]{3}{*}{ Tingkat Keamanan Lokasi } & Bangunan berada di lokasi yang mana & 35 & 24 \\
\hline & $\begin{array}{l}\text { Banjir dan longsor merupakan ancaman serius di lokasi } \\
\text { penelitian }\end{array}$ & 42 & 17 \\
\hline & Keamanan yang berpengaruh & 33 & 26 \\
\hline Total & & $56 \%$ & $44 \%$ \\
\hline \multirow[t]{3}{*}{$\begin{array}{l}\text { Tingginya Tingkat Pendapatan } \\
\text { di Area Perkotaan }\end{array}$} & $\begin{array}{l}\text { Pendapatan penduduk rata-rata di atas UMR yang } \\
\text { ditentukan oleh pemerintah provinsi }\end{array}$ & 34 & 25 \\
\hline & Pekerjaan tetap responden & 44 & 15 \\
\hline & Tingginya tingkat pendapatan yang berpengaruh & 8 & 51 \\
\hline Total & & $13,5 \%$ & $86,5 \%$ \\
\hline \multirow[t]{3}{*}{ Ketersediaan Kesempatan Kerja } & Terdapat tempat untuk bisnis di sekitar lokasi penelitian & 57 & 2 \\
\hline & $\begin{array}{l}\text { Responden memiliki pekerjaan sampingan untuk } \\
\text { memenuhi kebutuhan sehari-hari }\end{array}$ & 25 & 34 \\
\hline & Tingginya tingkat kesempatan kerja di lokas penelitian & 37 & 22 \\
\hline Total & & $63 \%$ & $37 \%$ \\
\hline \multirow[t]{3}{*}{ Kedekatan Dengan Lokasi Kerja } & Lokasi di pusat perkotaan & 57 & 2 \\
\hline & Transportasi mudah tersedia ke tempat kerja & 57 & 2 \\
\hline & Kedekatan jarak rumah ke tempat kerja & 57 & 2 \\
\hline Total & & $96.60 \%$ & $3.40 \%$ \\
\hline
\end{tabular}

\section{KESIMPULAN}

1. Ketidaksesuaian penggunaan ruang terjadi secara permanen yang dapat dilihat dengan 80 bangunan, yang sebagian besar berada di Kelurahan Bintang, Kecamatan Rangkui, yaitu 33 bangunan. Daerah sempadan sungai berdasarkan Peraturan Daerah Nomor 1 Tahun 2012 tentang Rencana Tata Ruang Teritorial di Kota Pangkalpinang adalah kawasan lindung dengan fungsi utama sebagai ruang terbuka hijau.

2. Faktor-faktor yang mempengaruhi ketidaksesuaian penggunaan sempadan Sungai Pedindang meliputi (1) ketersediaan fasilitas di sekitar lokasi sempadan sungai, (2) keamanan lokasi, (3) tingginya tingkat pendapatan di daerah perkotaan, (4) jumlah kesempatan kerja, dan (5) kedekatan dengan tempat kerja.

3. Ketidaksesuaian lahan yang digunakan di daerah sempadan Sungai Pedindang seluas $2.249 \mathrm{~m}^{2}$ dari total lebar bangunan $2.041 \quad \mathrm{~m}^{2}$.

\section{DAFTAR PUSTAKA}

Bappeda Kota Pangkalpinang. (2002). Rencana Tata Ruang Wilayah Kota Pangkalpinang Tahun 20022012. Bappeda Kota Pangkalpinang.

BappedaKota Pangkalpinang. (2011). Rencana Tata Ruang Wilayah Kota Pangkalpinang Tahun 20112030. Bappeda Kota Pangkalpinang.

Bijuri. (2005). Analisis Perubahan Pemanfaatan Lahan Pada Kiri Kanan di Sepanjang Jalan Arteri Antara Kota Banjarmasin dan Kota Banjarbaru. Tesis. Yogyakarta : Magister Perencanaan Kota dan Daerah, Universitas Gadjah Mada.

Bintarto. (1977). Interaksi Desa-Kota dan Permasalahannya. Jakarta : Ghalia Indonesia.

Badan Pusat Statistik Kota Pangkalpinang. (2006). Pangkalpinang dalam Angka Tahun 2005. BPS Kota Pangkalpinang.

Badan Pusat Statistik Provinsi Kepulauan Bangka Belitung. (2006). Pangkalpinang dalam Angka Tahun 2005. BPS Kota Pangkalpinang.

Badan Pusat Statistik Provinsi Kepulauan Bangka Belitung. (2010). Pangkalpinang dalam Angka Tahun 2009. BPS Kota Pangkalpinang. 
Badan Pusat Statistik Provinsi Kepulauan Bangka Belitung. (2014). Pangkalpinang dalam Angka Tahun 2013. BPS Kota Pangkalpinang.

Branch, Melvilli C. (1996). Perencanaan Kota Komprehensif (terjemahan). Yogyakarta : Gadjah MadaUniversity Press.

Budihardjo, Eko. (1997). Arsitektur Pembangunan dan Konservasi. Jakarta : Jambatan.

Chapin. F. S \& Kaiser E. J. (1979). "Urban Land Use Planning", Third.

David Krech dan Richard S. Cruthfield. (1948; 1968). Faktor-Faktor yang Menentukan dalam Proses Presepsi. Makalah Psikologi Pengertian Presepsi. Jakarta

Ester, R. K. (2006). Evaluasi Kesesuaian Pemanfaatan Ruang Aktual Terhadap Rencana Umum Tata Ruang Kota Medan, Periode 1991 - 2005 (Pada Wilayah Pengembangan Dan Pembangunan Pusat Kota). Skripsi. Yogyakarta : Fakultas Geografi Universitas Gadjah Mada.

Freeman. (1984). Strategic Management: A Stakeholder Approach on community Development. Edisi July. USA : Boston.

Hermit, Herman. (2008). Pembahasan Undang Undang Penataan Ruang (UU No.26 Tahun 2007).

Bandung : Mandar Maju.

Jayadinata. Tata Guna Tanah Dalam Perencanaan Desa, Perkotaan dan Wilayah. Bandung : Institut Teknologi Bandung.

Kodoatie. 2003. Manajeman dan Rekayasa Infrastruktur. Yogyakarta : Pustaka Pelajar.

Maryono, Agus. (2014). Pengelolaan Kawasan Wilayah Sempadan. Yogyakarta : Gadjah Mada University Press.

Mudadtzir. (2002). Kajian Dampak Lingkungan Penyimpanan Peruntukan Ruang Tahun 1997-2002 Menurut RTRK Benteng Tahun 1997-2007 Kbupaten Selayar Sulawesi Selatan. Tesis. Yogyakarta : Magister Pengelolaan Lingkungan, Fakultas Geografi Universitas Gadjah Mada.
Ridwansyah, T. (2000). Evaluasi Pelaksanaan Kebijakan Tataruang di Kota Kendari. Tesis. Yogyakarta : Magister Administrasi Publik, Universitas Gadjah Mada.

Ritohardoyo, Su. (2008). Garis Besar Perkuliahan Teori Keruangan. Yogyakarta : Fakultas Geografi, Program Studi Ilmu Lingkungan, Universitas Gadjah Mada.

Yunus, H. S. (2005). Manajemen Kota Prespektif Spasial. Yogyakarta : Pustaka Pelajar Offset.

Yunus, H. S. (2005). Klasifikasi Kota. Yogyakarta : Pustaka Pelajar Offset.

Yunus, H. S. (2008). Dinamika Wilayah Peri Urban, Faktor Penentu Masa Depan Kota. Yogyakarta : Pustaka Pelajar Offset.

\section{Peraturan Perundang-undangan}

Undang Undang Nomor 23 tahun 1997 tentang Pengelolaan Lingkungan Hidup.

Undang Undang Nomor 27 Tahun 2000 tentang Pembentukan Provinsi Kepulauan Bangka Belitung.

Undang Undang Nomor 26 tahun 2007 tentang Penataan Ruang.

Peraturan Pemerintah Nomor 38 Tahun 2011 tentang Sungai.

Keputusan Menteri Pekerjaan Umum Nomor 327/KPTS/M/2002 tentang Penetapan Enam Pedoman Bidang Penataan Ruang.

Perda No 4 Tahun 2002 tentang Rencana Tata Ruang Wilayah Pangkalpinang Municipality Tahun 20022012.

Perda No 5 Tahun 2010 tentang Perubahan Atas Peraturan Daerah No 14 Tahun 2002 Tentang Pengawasan, Pengendalian Kawasan Lindung dan Konservasi Sumber Daya Alam.

Perda No 1 Tahun 2012 tentang Rencana Tata Ruang Wilayah Teritorial di Kota Pangkalpinang Tahun $2011-2030$. 